\title{
ANTICIPATORY BREEDING: MOLECULAR MARKERS AS A TOOL IN DEVELOPING DONORS OF POTATO (Solanum tuberosum L.) LATE BLIGHT RESISTANCE FROM COMPLEX INTERSPECIFIC HYBRIDS
}

\section{O.A. FADINA ${ }^{1}$, M.P. BEKETOVA ${ }^{1}$, E.A. SOKOLOVA ${ }^{1}$, M.A. KUZNETSOVA ${ }^{2}$, T.I. SMETANINA ${ }^{2}$, E.V. ROGOZINA ${ }^{3}$, E.E. KHAVKIN ${ }^{1}$}

\begin{abstract}
${ }^{1}$ All-Russian Research Institute of Agricultural Biotechnology, Federal Agency of Scientific Organizations, 42, ul. Timiryazevskaya, Moscow, 127550 Russia, emil.khavkin@gmail.com;

${ }^{2}$ All-Russian Research Institute of Phytopathology, Federal Agency of Scientific Organizations, 5, ul. Institute, pos. Bol'shie Vyazemy, Odintsovskii Region, Moscow Province, 143050 Russia, e-mail kuznetsova@vniif.ru;

${ }^{3}$ Federal Research Center the N.I. Vavilov All-Russian Institute of Plant Genetic Resources, Federal Agency of Scientific Organizations, 42-44, ul. Bol'shaya Morskaya, St. Petersburg, 190000 Russia ORCID:

Fadina O.A. orcid.org/0000-0002-6600-1693

Beketova M.P. orcid.org/0000-0002-3104-5303

Sokolova E.A. orcid.org/0000-0002-8801-2879

Kuznetsova M.A. orcid.org/0000-0002-9880-5995

The authors declare no conflict of interests

Acknowledgements:

The authors thank the Center for Collective Use of Equipment «Biotechnology» (All-Russian Research Institute of Agricultural Biotechnology) for sequencing Solanum genome fragments.

Supported by the ISTC-ARS-USDA (project № 3714p), by the Ministry of Education and Science of the Russian Federation (contract № 16.M04.12.0007), and by Russian Foundation for Basic Research (projects № 13-0400163/14, № 14-04-31613a, and № 16-04-00098). Development of potato interspecific hybrids, phytopathological evaluation of Phytophthora infestans isolates, evaluation of potato late blight resistance and marker analysis of potato genotypes were performed in the framework of the State Tasks 0662-2014-0018, 0598-2015-0018, 0598-2015-0016 and 0574-2014-0020, respectively

Smetanina T.I. orcid.org/0000-0001-5698-7703

Rogozina E.V. orcid.org/0000-0002-2743-068X

Khavkin E.E. orcid.org/0000-0001-9177-3997
\end{abstract}

Received September 26, 2016

\section{Abstract}

Potato late blight caused by oomycete Phytophthora infestans Mont de Bary remains the most significant agronomic and economic problem of potato husbandry. The unique rate of evolution of this pathogen as well as its migration are a major obstacle to producing varieties with durable late blight resistance. The best way to counter this threat is the anticipatory breeding based on donors that carry genes of resistance to a wide range of pathogen races. Combining multiple genes for late blight resistance in the same plant (pyramiding of genes) makes such resistance durable. The most promising way of obtaining such donors is introgression breeding of interspecific potato hybrids with resistance genes transferred from potato wild relatives - the tuber-bearing species of Solanum L. Molecular markers allowing to reliably distinguish between resistance genes of diverse specificity and successfully control their transfer in the process of crossing and selecting, dramatically increase the efficiency of introgression breeding for late blight resistance. We examined about 40 complex hybrids bred in the A.G. Lorkh All-Russian Research Institute of Potato Husbandry, the N.I. Vavilov AllRussian Institute of Plant Genetic Resources and the All-Russian Research Institute of Plant Protection using the germplasm of 16 species of tuber-bearing Solanum, and further maintained as clones. Each of these clones carries the genetic material introgressed from two to eight wild species established as the sources of resistance to late blight. Most of these clones have manifested, from year to year, high late blight resistance in field trials under natural infection and in vitro studies when detached leaves were infected with a highly virulent and aggressive isolate of $P$. infestans. SCAR (sequence-characterized amplified region) markers, the fragments of $R$ genes of race-specific (vertical) resistance to late blight discerned in various Solanum species, were employed to screen the clones of interspecific hybrids. The information on the presence of SCAR markers for six $R$ genes, i.e. $R 1$ (chromosome 5), R2/Rpi-blb3 (chromosome 4), R3a and $R 3 b$ (chromosome 11), RB/Rpi-blb1 $=$ Rpisto1 (chromosome 8), and Rpi-vnt1.3 (chromosome 9), was juxtaposed against the indices of late blight resistance. Comparison of the resistance of the clones of interspecific hybrids and potato varieties devoid of $R$ gene marker presumes a significant contribution of these genes to general late blight resistance of potato plants. The higher number of $R$ gene markers per plant corresponded to superior late blight resistance. Presumably, future use of these clones for pyramiding resistance genes under the control of molecular markers will enable target introgression breeding. Such approach will 
streamline developing new potato varieties with durable late blight resistance to maintain high productivity even after significant changes in the populations of $P$. infestans.

Keywords: potato late blight, interspecific potato hybrids, wild Solanum species, introgression breeding, $R$ genes for late blight resistance, $A v r$ genes of $P$. infestans

Late blight caused by oomycete Phytophthora infestans Mont. de Bary remains one of the most economically significant potato diseases which results in losses of at least $15 \%$ of yield annually, and global economic damage, including expenses for chemicals for pathogen control, amounts to 10 bln US dollars [1]. Late blight epidemics of new $P$. infestans races due to the pathogen evolution and migration periodically destroy up to 70-100\% of yield [2-4]. Thus, varieties with durable resistance to a wide range of $P$. infestans, ensuring significant preservation of plant productivity in case of changes of the pathogen race composition in agrocenosis, are required for successful potato farming. Development of such varieties may be referred to as preventive breeding.

The sources of resistance to $P$. infestans, the Solanum L. species (section Petota Dumort.), play the defining role in this approach. Resistance genes have been identified in many representatives of Solanum genus from North and South America [5], but only a few of them are available in commercial potato varieties (https://www.europotato.org). Development of interspecies hybrids on the basis of $S$. demissum was one of the first examples of introgression of such racespecific vertical resistance genes ( $R$ genes) obtained from wild species [6, 7]; however, new races of $P$. infestans quickly overcame the stability obtained using this method [8]. Horizontal late blight resistance [8-10] common to a wide range of tuberiferous Solanum species is controlled by numerous race-nonspecific genes. They are mainly mapped as quantitative trait loci (QTL) only and explored to a lesser extent, as compared to race specific genes $[5,11,12]$. Expression of race-nonspecific genes depends heavily on external factors, which significantly complicated the work on breeding for horizontal late blight resistance.

Involvement of genetic sources in development of breeding-valuable trait donors takes place during pre-breeding selection. Collections of cultivated and wild tuberiferous Solanum species has been developed in N.I. Vavilov AllRussian Institute of Plant Genetic Resources (VIR, St. Petersburg) is one of the world largest ones. Here genetic centers of late blight resistant species formation have been identified [13], and genetic bases for obtaining of interspecies donor hybrids [14] and collection of samples suitable for interspecies hybridization have been developed.

Complex interspecies hybrids with genetic material of several wild Solanum species may become the best donors for development of resistant potato varieties $[10,15,16]$, and stacking (combining) of different late blight resistance genes in a single plant ensures durability of this resistance. As a rule, wild congeners of potato and hybrids involving them contain several $R$ genes with different race specificity [17]; $P$. infestans race sets, with virulence factors determined using Mastenbroek and Black differential varieties, are normally used for their recognition [7, 18]. These differential races only identify $11 R$ genes of $S$. demissum (not all of which are cloned) and do not recognize other genes which may be present in Solanum species. Some of these differential plants have more than one $R$ gene [19]. Avirulence gene ipiO, identifying $R B / R p i-b l b 1$ gene in potato, which is common to $S$. bulbocastanum and absent in $S$. demissum [20], is represented by two classes in $P$. infestans differential races.

Many problems of this kind have been solved by development of monogenic differential plants [21]. However, in this case the use of $P$. infestans races with known virulence genes will probably fail to provide the same $R$ gene identification 
accuracy, as compared to their direct identification using molecular markers. Thus, effective search of resistance genes specific for a wide range of $P$. infestans races and their stacking are primarily based on molecular marking.

Markers representing resistance gene fragments are most suitable for review of large genetic collections and control of the results during breeding. Such SCAR (sequence characterized amplified region) markers, unlike flanking markers, completely preserve informative value even in case of significant recombination of genetic material in hybrid genomes. The main problem arising during the use of these markers is the necessity to distinguish functionally active genes from their inactive structural homologs. It should be noted that effectoromics methods [22] ensure more specific recognition of $R$ resistance genes in plants: individual pathogen avirulence genes ( $A v r$ genes) are introduced in a plant as part of a vector, and evident hypersensitivity reaction indicates the presence of the respective $R$ gene. This methodological approach has limitations as well, and the best results are achieved by combining of two complementary techniques.

This work presents the first data summary of long-term studies of collections of complex interspecies hybrids and potato hybrids, included in parentage of such hybrids or used as reference standards during evaluation of late blight resistance (some results were previously presented at EuroBlight Workshops, 2013, 2015; http://euroblight.net/). The performed summary allowed us to propose a new approach to development of varieties with durable resistance to late blight. This approach is based on development of a method of controlled introgressive breeding of complex interspecies potato hybrids with high late blight resistance, achieved by stacking of $R$ resistance genes, controlled by molecular markers of these genes. A large pool of such hybrids used as breeding donors allows quick response to changes in pathogen population composition.

Application of the approach aimed at preventive breeding and problems related to it will be illustrated below, through the example of two groups of interspecies hybrids.

Techniques. The research included 10 varieties (Alpha, Desiree, Bintje, Early Rose, Eesterling, Escort, Gloria, Elizaveta, Svitanok kievsky and Sarpo Mira), Atzimba variety dihaploid and 39 clones of complex interspecies potato hybrids obtained in A.G. Lorkh All-Russian Research Institute of Potato Husbandry (Moscow region), N.I. Vavilov All-Russian Institute of Plant Genetic Resources (VIR, St. Petersburg) and All-Russian Research Institute of Plant Protection (St. Petersburg) with participation of 16 tuberiferous Solanum species from various centers of origin.

Late blight resistance of leaves was evaluated in long-term field trials in two regions of the Russian Federation, i.e. Northwest (VIR) and Central (AllRussian Research Institute of Phytopathology, VNIIF) in conditions of natural infection. Varieties Elizaveta, Udacha, Nayada and Petersburgskii (VIR) or Alpha, Bintje, Eesterling, Escort, Gloria, Robijn and Sarpo Mira (VNIIF) served as reference standards. During laboratory tests detached leaves of plants grown in a greenhouse were infected with a highly virulent and aggressive isolate of $P$. infestans (races 1-11) from VNIIF collection, with Santé variety used as a reference standard [23].

Genomic DNA was extracted from leaves using AxyPrep ${ }^{\mathrm{TM}}$ Multisource Genomic DNA Miniprep Kit (Axygen Biosciences, USA). DNA concentration was measured at $\lambda=260 \mathrm{~nm}$ using UV/Vis NanoPhotometer P300 nanophotometer (IMPLEN, Germany). Genomic DNA amplification, cloning and amplicon sequencing methods have been described by us earlier [24]. PCR was performed in a DNA amplifier DNA Engine PTC-200 (Bio-Rad, USA) with 1.0 unit of Taq DNA polymerase (Fermentas, USA), and for R2-2500 marker with 
2.5 units of Pfu DNA polymerase (Fermentas, USA). QIAquick Gel Extraction Kit (Qiagen N.V., Germany) was used for elution of target DNA fragments, pGEM-T Easy Vector System I (Promega, USA) was used for cloning; for R22500 marker Thermo Scientific ${ }^{\mathrm{TM}}$ CloneJET $^{\mathrm{TM}}$ PCR Cloning Kit and pJet vector (Fermentas, USA) were used. Sequencing was performed using ABI PRISM 3130xl (Applied Biosystems, USA) or Nanofor 05 (Analytical Instrument Engineering Institute of RAS, Russia). The primers were synthesized by ZAO Syntol (Russia). Sequenced fragments were assembled using SeqMan package, Lasergene 7.0 (available at http://www.dnastar.com).

Correlation analysis was performed using Statistica 6.0 software (StatSoft Inc., USA; available at http://www.statsoft.com/) with evaluation of Pearson's parametric correlation and Spearman's rank correlation, as well as using Wilcoxon's nonparametric test. All correlation coefficients were significant at $\mathrm{p}<0.05$.

Results. Work with clone collections of potato varieties and hybrids [15] maintained in VIR and VNIIF allows comparison of the results of independent test in several laboratories and significantly increases reproducibility of trials. Each interspecies clone studies by us carries genetic material of various late blight resistance sources and has $2-8$ wild potato species in parentage (a significant part of them is provided below).

In field conditions at natural $P$. infestans infection the majority of the studied interspecies hybrid clones demonstrated high resistance to late blight every year, which was comparable to that of the reference variety Sarpo Mira (8 points). High resistance of clones (up to 7 points) was registered in laboratory tests as well.

The differences between the field and laboratory test results (1-3 points) for the majority of potato hybrid and variety clones can be explained by more favorable conditions for pathogen development in the laboratory test [3] and the contribution of other plant organs to general resistance [25]. In cases when these differences are especially big, significant activity of race-nonspecific resistance genes can also be expected. Field and laboratory resistance indices are closely related (Pearson's correlation coefficient 0.963 is significant at $\mathrm{p}<0.01$ ).

1. Sequence characterized amplified region (SCAR) characteristic of potato (Solanum $\mathrm{L}$.) $R$ late blight resistance gene markers used in the work

\begin{tabular}{|c|c|c|c|c|}
\hline Gene & $\begin{array}{l}\text { Marker with indica- } \\
\text { tion of length (-bps) }\end{array}$ & $\begin{array}{l}\text { Annealing } \\
\text { temperature, } \\
{ }^{\circ} \mathrm{C}\end{array}$ & $\begin{array}{l}\text { Forward }(F) \text { and reverse }(R) \text { primers } \\
\left(5^{\prime} \rightarrow 3^{\prime}\right)\end{array}$ & $\begin{array}{l}\text { Refer- } \\
\text { ence }\end{array}$ \\
\hline$R p i-b l b 1$ & Rpi-blb1-820 & 62 & $\begin{array}{l}\text { F: AACCTGTATGGCAGTGGCATG } \\
\text { R: GTCAGAAAAGGGCACTCGTG }\end{array}$ & [27] \\
\hline Rpi-sto $1=R p i-b l b 1$ & Rpi-sto1-890 & 65 & $\begin{array}{l}\text { F: ACCAAGGCCACAAGATTCTC } \\
\text { R: CCTGCGGTTCGGTTAATACA }\end{array}$ & [28] \\
\hline R1 & R1-1205 & 65 & $\begin{array}{l}\text { F: CACTCGTGACATATCCTCACTA, } \\
\text { R: GTAGTACCTATCTTATTTCTGCAAGAAT }\end{array}$ & [24] \\
\hline$R 2$ & $\mathrm{R} 2-2500$ & 62 & $\begin{array}{l}\text { F: ATGGCTGATGCCTTTCTATCATTTGC } \\
\text { R: TCACAACATATAATTCCGCTTC }\end{array}$ & [19] \\
\hline$R 3 a$ & R3-1380 & 64 & $\begin{array}{l}\text { F: TCCGACATGTATTGATCTCCCTG } \\
\text { R: AGCCACTTCAGCTTCTTACAGTAGG }\end{array}$ & [24] \\
\hline$R 3 b$ & R3b-378 & 64 & $\begin{array}{l}\text { F: GTCGATGAATGCTATGTTTCTCGAGA } \\
\text { R: ACCAGTTTCTTGCAATTCCAGATTG }\end{array}$ & [29] \\
\hline Rpi-vnt 1.3 & Rpi-vnt1.3-612 & 65 & $\begin{array}{l}\text { F: CCTTCCTCATCCTCACATTTAG } \\
\text { R: GCATGCCAACTATTGAAACAAC }\end{array}$ & [30] \\
\hline
\end{tabular}

Well-verified SCAR markers of 6 race-specific late blight resistance $R$ genes localized in six of 12 potato chromosomes were selected for screening: $R 1$ (chromosome 5), R2/Rpi-blb3 (chromosome 4), R3a and R3b (chromosome 11), $R B / R p i-b l b 1=R p i$-sto 1 (chromosome 8) and Rpi-vnt1.3 (chromosome 9) (Table $1)$. These markers have been developed for late blight resistance $R$ genes, initially characterized in four Solanum species, S. bulbocastanum, S. demissum, S. stolon- 
iferum and $S$. venturii.

Two contrast groups of potato genotypes were selected to illustrate the screening results (Table 2). These are hybrids with 3-4 $R$ resistance gene markers corresponding to high late blight (these forms constitute the majority of interspecies hybrids studied by us) and hybrids with high resistance and small number of markers.

2. Distribution of sequence characterized amplified region (SCAR) $R$ gene markers in two groups of interspecies potato (Solanum L.) hybrids of different origin with high late blight resistance

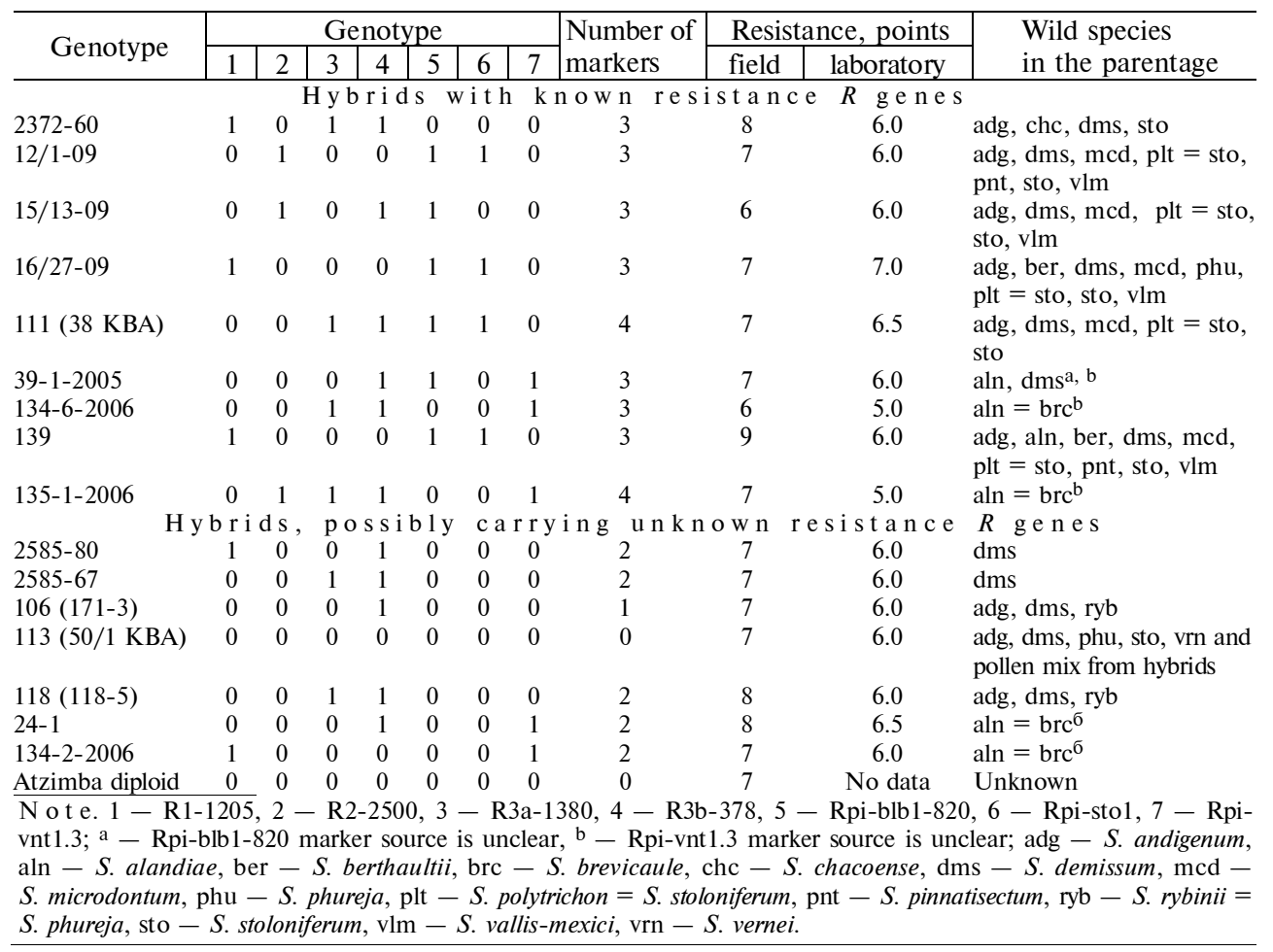

The markers used by us have been developed for late blight resistance $R$ genes initially characterized in four Solanum species, $S$. bulbocastanum, S. demissum, S. stoloniferum and $S$. venturii. Comparison of interspecies potato hybrid clones and wild Solanum species used during development of these hybrids [24, 26] has confirmed that the composition of $R$ genes in hybrids mostly corresponded to their parentages. $R 1, R 2, R 3 a$ and $R 3 b$ gene markers were most probably transferred from $S$. demissum, however, according to screening of the large collection of wild Petota section species [24], they could originate from other wild species indicated in parentages. Genetic material of $S$. bulbocastanum was nor used for development of the studied hybrids, and in cases where we identify Rpi-blb1 gene marker, it was transferred from $S$. stoloniferum, a tetraploid species; presumably, one of its genomes originates from $S$. bulbocastanum [27]. The screening results sufficiently correlate with Rpi-blb1-820 and Rpi-sto1890 markers which correspond to two gene regions $R p i$-blb1 $=R p i$-sto 1 , located at a significant distance from each other. The presence of $R 1$ gene in $S$. stoloniferum has been confirmed by detailed studies of this specie [31], including cloning of a full-size $R 1$ ortholog (GenBank accession number KU302613, National Center for Biotechnology Information - NCBI, USA); apart from that, the presence of $R 1$ functional gene in $S$. stoloniferum has been confirmed using effectoromics method [32]. 
In some cases interpretation of the obtained data is impossible without further in-depth studies. This relates to Rpi-blb1-820 and Rpi-sto1 markers present in hybrids without $S$. stoloniferum specie in parentage. We have also discovered Rpi-vnt1.3 gene marker in the majority of markers, origin of which is not related to $S$. venturii. This is consistent with the recent report [30] on the presence of structural homologs of the said genes in S. microdontum ssp. gigantophyllum and S. phureja (NCBI GenBank accession numbers GU338312, GU338337). Cloning of SCAR markers of $R$ genes from interspecies hybrids performed by us has demonstrated that nucleotide sequences of these markers are $98-100 \%$ identical to prototype genes. In cases where variations are observed, they can be attributed to species (allelic) diversity of $R$ genes within Petota polymorphic section [33]. It appears that the studied $R$ genes are common beyond the species in which they were described for the first time, i.e. more common than it was suggested earlier. The same was confirmed by the results of Solanum wild species screening performed by us earlier [17, 24, 26, 33]. Similar results were obtained by H. Rietman using effectoromics method [32].

Correlation of the presence of a marker with availability of a functional $R$ gene is the most important question during marker analysis of wild and cultivated potato species. Even complete similarity of marker sequence and prototype gene does not serve as evidence of functional activity: structural differences may be beyond the marker borders, and a single nucleotide substitution is sufficient for change of $R$ gene product (kinase) function [34]. Possibly, the use of specific $A v r$ genes distinguishing functional $R$ genes from their inactive homologs will provide more clear answer [22].

Correlation between the presence of these markers and late blight resistance of plants is a circumstantial evidence of functional activity of $R$ genes identified using SCAR markers. The Figure shows the correlation between field and laboratory resistance of 40 potato hybrids and varieties and the number of $R$ resistance gene markers per plant as a characteristic of late blight resistance genes stacking. Forty genotypes were selected for calculations, i.e. 10 varieties with low and high resistance and all hybrids, except for forms with presumably unknown resistance genes (see bottom of Table 2). Indeed, in this case resistance of plants as per results of field and laboratory tests is closely related to the presence of $R$ gene markers: the respective Pearson's parametric correlation coefficients $(0.74$ and 0.67$)$ and Spearman's rank correlation coefficients $(0.66$ and 0.64$)$ were significant at $\mathrm{p}<0.01$, and correlation as per Wilcoxon's test at $\mathrm{p}<0.05$. These data are indicative of evident contribution of race-specific genes to late blight resistance of potato plants [12].

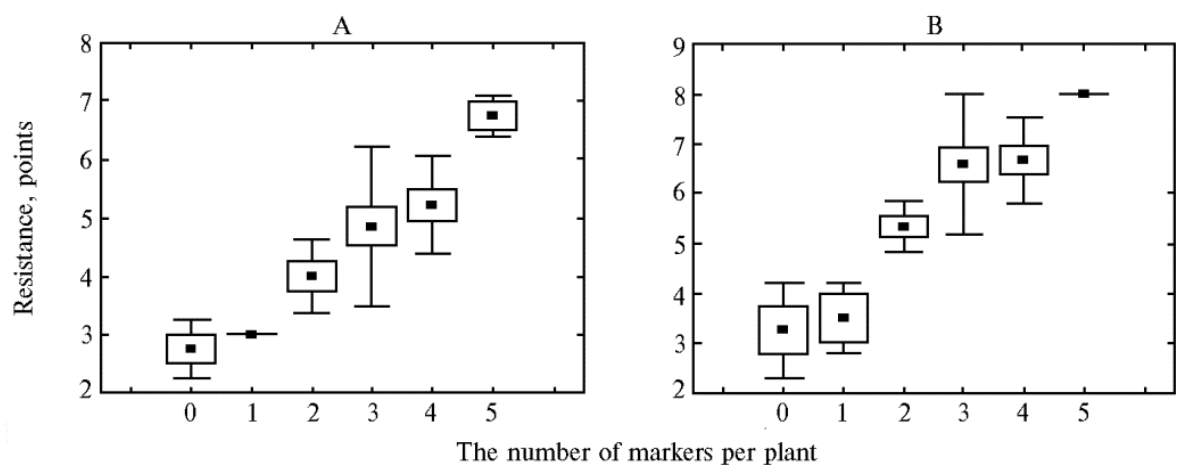

Correlation of laboratory (A) and field (B) late blight resistance of potato (Solanum tuberosum L.) plants with the number of $\boldsymbol{R}$ gene markers: - - mean, $\square-$ mean $\pm \mathrm{SEM}$, I- mean $\pm \mathrm{SD}$.

Resistance increased with increase in the number of $R$ gene markers 
transferred by hybridization method (see Fig.). It suggests that further crossings for gene accumulation and selection of the best resistance gene combinations, controlled by $R$ gene markers will allow combining more resistance genes in a single plant, as compared to modern genetic engineering techniques [1].

A small group of interspecies potato hybrids, which was not included in the above mentioned statistical analysis, is of particular interest. They are characterized by high late blight resistance, but do not contain the expected large number of $R$ gene markers (see Table 2). It was found that these forms include Atzimba variety dihaploid as well. These forms probably carry race-specific and race-nonspecific resistance genes, which cannot be detected with the markers used. Currently we are performing work on development of markers to these genes and their validation for selection screening.

Thus, the best method of prevention of new $P$. infestans races emergence is preventive breeding, i.e. development of breeding donors for late blight on the basis of interspecies hybrids with resistance genes transferred from wild potato congeners. Durable resistance of these hybrids is determined by stacking several $R$ genes (jointly they ensure recognition of pathogen races with a wide specificity range and quick response even to rapid changes in $P$. infestans populations). This problem can be solved by search of new initial material among cultivated and wild forms of Solanum L., Petota section (wild species previously not involved in crossing are of particular interest) and development of interspecies donor hybrids pool with several resistance genes by means of introgressive MAS.

Currently this pool maintained as clone collections of VIR, All-Russian Research Institute of Potato Husbandry and All-Russian Research Institute of Phytopathology contains more than 60 interspecies potato hybrids characterized using morphophysiological, phytopathological and molecular methods, which are unique in agriculturally valuable gene composition and represent ready-to-use breeding material for variety development within short timeframes. They are obtained by traditional hybridization methods, which are more labour- and timeconsuming, as compared to genetic transformation using two or three resistance genes with wide specificity. However, the number of agriculturally valuable genes per plant in these hybrids and ability to resist a larger number of $P$. infestans races of the described clones is higher, as compared to forms developed using genetic engineering techniques. Another benefit of breeding donors on the basis of interspecies hybrids is preservation of genetic environment inherited from parental forms (including horizontal resistance genes) for introgressed race-specific resistance genes. This ensures stability of developed varieties and slows down selections of more adapted pathogen forms in crops.

Thus, the use of resistance gene molecular markers in introgressive breeding is a transition to the development of conceptually new breeding donors. We have demonstrated the substantial contribution of $R$ genes to late blight resistance of potato plants, which increases significantly in case of stacking genes with different specificity, through the example of potato hybrids carrying genetic material of several wild Solanum species. Our studies of interspecies hybrid clones using markers of $6 R$ genes allowed identification of two genotype groups: unique donors for development of new varieties, and the hybrids carrying rare alleles of resistance genes which makes them promising, first of all, as initial material for search and isolation of previously unknown $R$ genes. Further stacking of resistance genes by crossings, using thoroughly characterized donors and molecular markers, will allow development of potato varieties able to preserve productivity even in case of significant changes in Phytophthora infestans populations in the nearest future. This, in its turn, requires studies of resistant gene specificity and development of reliable markers for 


\section{RE F E R E N C ES}

1. Haverkort A.J., B o o nekamp P.M., Hutten R., J a cobsen E., Lotz L.A.P., Kess e 1 G.J.T., Voss e $n$ J.H., Viss e $r$ R.G.F. Durable late blight resistance in potato through dynamic varieties obtained by cisgenesis: Scientific and societal advances in the DuRPh project. Potato Res., 2016, 59(1): 35-66 (doi: 10.1007/s11540-015-9312-6).

2. Cooke D., Cano L., Raffaele S., B a in R., Cooke L., Etherington G.J., D e ah 1 K.L., Farrer R.A., Gilroy E.M., Goss E.M., Grũ nwald N.J., He i n I, Mac Lean D, Mc Nicol J.W., Randall E, Oliva R.F., Pel M.A., Shaw D.S., Squires J.N., Taylor M.C., Vle es houwe rs V.G., B irch P.R., Lees A.K., $\mathrm{Ka}$ m o u $\mathrm{S}$. Genome analyses of an aggressive and invasive lineage of the Irish potato famine pathogen. PLoS Pathol., 2012, 8(10): e1002940 (doi: 10.1371/journal.ppat.1002940).

3. Fry W.E. Phytophthora infestans: New tools (and old ones) lead to new understanding and precision management. Annu. Rev. Phytopathol., 2016, 54: 529-547 (doi: 10.1146/annurevphyto-080615-095951).

4. Lees A.K., Stewart J.A., Lynott J.S., Carnegie S.F., Campbell H., Rob e rts A.M. The effect of a dominant Phytophthora infestans genotype (13_A2) in Great Britain on host resistance to foliar late blight in commercial potato cultivars. Potato Res., 2012, 55(2): 125-134 (doi: 10.1007/s11540-012-9214-9).

5. Śliwka J., Zi mnoch-Guzowska E. Resistance to late blight in potato. In: Translational genomics for crop breeding: biotic stress. R.K. Varshney, R. Tuberosa (eds.). John Wiley \& Sons Ltd, Chichester, UK, 2013, V. 1: 221-240 (doi: 10.1002/9781118728475.ch12).

6. R o s s H. Potato breeding: problems and perspectives. Paul Parey, Berlin, 1986.

7. B radsh aw J. Potato breeding at the Scottish Plant Breeding Station and the Scottish Crop Research Institute: 1920-2008. Potato Res., 2009, 52(2): 141-172 (doi: 10.1007/s11540-009-9126-5).

8. W a s t i e R.L. Breeding for resistance. Adv. Plant Pathol., 1991, 7: 193-224.

9. Kolobaev V.A. Printsipy $i$ metody sozdaniya vysokoeffektivnykh donorov gorizontal'noi ustoichivosti kartofelya $k$ fitoftorozu [Principles and methods to create highly effective donors of potato horizontal resistance to late bligh]. St. Petersburg, 2001 (in Russ.).

10. Y a s hin a I.M., Prokhorova O.A., Kukush ki na L.N. Dostizheniya nauki $i$ tekhniki $A P K, 2010,12: 17-21$ (in Russ.).

11. D a n a n S., V e y rie ras J.-B., Le f e bvre V. Construction of a potato consensus map and QTL meta-analysis offer new insights into the genetic architecture of late blight resistance and plant maturity traits. BMC Plant Biol., 2011, 11: 16 (doi: 10.1186/1471-2229-11-16).

12. G e b hardt C. Bridging the gap between genome analysis and precision breeding in potato. Trends Genet., 2013, 29(4): 248-256 (doi: 10.1016/j.tig.2012.11.006).

13. B u d i n K.Z. Sel'skokhozyaistvennaya biologiya [Agricultural Biology], 1999, 5: 9-14 (in Russ.).

14. B u d i n K.Z. Geneticheskie osnovy sozdaniya donorov kartofelya [Genetic basis to create potato donors]. St. Petersburg, 1997 (in Russ.).

15. Rogozina E.V., Khavkin E.E., Sokolova E.A., Kuznetsova M.A., Gavrile nko T.A., Li man t s e v L.A., B i ry u kova V.A., Chal ay a N.A., D z ho ns R.V., D i 1 K.L. Trudy po prikladnoi botanike, genetike i selektsii (VIR), 2013, 174: 23-32 (in Russ.).

16. Kuznetsova M.A., Prokhorova O.A., Rogozhin A.N., S metanina T.I., Khavkin E.E., Yashina I.M. Sposob otbora gibridov kartofelya s vysokoi polevoi ustoichivost'yu $k$ fitoftorozu. Patent RU № 2560725 C2, 2015 [Patent RU 2560725 C2, 2015. A method of screening potato hybrids with high field resistance to late blight. Priority date April 29, 2013].

17. Khavkin E.E., Fadina O.A., Sokolova E.A., Beketova M.P., Drobyazina P.E., Rogozina E.V., Kuznetsova M.A., Yashina I.M., Jones R.W., Deahl K.L. Pyramiding $R$ genes: genomic and genetic profiles of interspecific potato hybrids and their progenitors. In: PPO-Special Report no. 16. H.T.A.M. Schepers (ed.). Wageningen, 2014: 215-220.

18. B la ck W., Mas te nbroek C., Mills W.R., P e terson L.C. A proposal for an international nomenclature of races of Phytophthora infestans and of genes controlling immunity in Solanum demissum derivatives. Euphytica, 1953, 2(3): 173-179 (doi: 10.1007/BF00053724)

19. K i m H.-J., Lee H.-R., Jo K.-R., Mortazavian S.M.M., Huigen D.J., Even$\mathrm{hu}$ is B., Ke s s e 1 G., Vis s e r R.G.F., J a c obse n E., Vos s e n J.H. Broad spectrum of late blight resistance in potato differential set plants MaR8 and MaR9 is conferred by multiple stacked $R$ genes. Theor. Appl. Genet., 2012, 124(5): 923-935 (doi: 10.1007/s00122-011-1757-7).

20. Pankin A., Kinash E., Rogozina E., Kozlovskaya I., Kuznetsova M., Khavkin E. Are simple Phytophthora infestans races that simple? In: PPO-Special Report. Wageningen, 2012, V. 15: 205-211.

21. Zhu S., Vossen J.H., B ergervoet M., Nijenhuis M., Kodde L., Kesse 1 G.J.T., Vle e s houwe rs V., Vis s e r R.G.F., J a c obsen E. An updated conventional and a novel GM potato late blight $R$ gene differential set for virulence monitoring of Phy- 
tophthora infestans. Euphytica, 2015, 202(2): 219-234 (doi: 10.1007/s10681-014-1276-0).

22. Du J., Vle eshouwers V.G. The do's and don'ts of effectoromics. In: Plant-pathogen interactions: methods and protocols. P. Birch, J. Jones, J. Bos (eds.). Springer, NY, 2014: 257268 (doi: 10.1007/978-1-62703-986-4_19).

23. Kuznetsova M.A., Spiglazova S.Yu., Rogozhin A.N., S metanina T.I., Fil i p p o v A.V. New approaches for measuring potato susceptibility to Phytophthora infestans. In: PPO-Special Report no. 16. H.T.A.M. Schepers (ed.). Wageningen, 2014: 223-232.

24. Sokolova E., Pankin A., Beketova M., Kuznetsova M., Spiglazova S., Rogozina E., Yashina I., Khavkin E. SCAR markers of the $R$-genes and germplasm of wild Solanum species for breeding late blight-resistant potato cultivars. Plant Genetic Resources, 2011, 9(2): 309-312 (doi: 10.1017/S1479262111000347).

25. Orłowska E., Llorente B., Cvitanich C. Plant integrity: an important factor in plant-pathogen interactions. Plant Signal. Behav., 2013, 8(1): e22513 (doi: 10.4161/psb.22513).

26. Sokolova E.A., Fadina O.A., Khavkin E.E., Rogozina E.V., Kuznetsov a M.A., J o n e s R.W., D e a h 1 K.L. Structural homologues of CC-NBS-LRR genes for potato late blight resistance in wild Solanum species. In: PPO-Special Report no. 16 /H.T.A.M. Schepers (ed.). Wageningen, 2014: 247-253.

27. Wang M., Allefs S., van den Berg R.G., Vleeshouwers V.G., van der Vossen E.A., Vosman B. Allele mining in Solanum: conserved homologues of Rpi-blb1 are identified in Solanum stoloniferum. Theor. Appl. Genet., 2008, 116(7): 933-943 (doi: 10.1007/s00122-008-0725-3).

28. Haesaert G., Vossen J.H., Custers R., de Loose M., Haverkort A., Heremans B., Hutten R., Kessel G., Landschoot S., Van Droogenb ro e ck B., Visse r R.G.F., Ghe ys e n G. Transformation of the potato variety Desiree with single or multiple resistance genes increases resistance to late blight under field conditions. Crop Protect., 2015, 77, 163-175 (doi: 10.1016/j.cropro.2015.07.018).

29. Rietman H., Bijsterbosch G., Cano L.M., Lee H.R., Vossen J.H., Jacobsen E., Vis se r R.G., Kamoun S., Vle es shouwers V.G. Qualitative and quantitative late blight resistance in the potato cultivar Sarpo Mira is determined by the perception of five distinct RXLR effectors. Mol. Plant-Microbe Interact., 2012, 25(7): 910-919 (doi: 10.1094/MPMI-01-12-0010-R).

30. Pel M.A., Foster S.J., Park T.H., Riet man H., van Arkel G., Jones J.D., Van Eck H.J., Jacobsen E., Visser R.G.F., Van der Vossen E.A. Mapping and cloning of late blight resistance genes from Solanum venturii using an interspecific candidate gene approach. Mol. Plant-Microbe Interact., 2009, 22(5): 601-615 (doi: 10.1094/MPMI-22-5-0601.).

31. Beketova M., Pankin A., Sokolova E., Rogozina E., Kuznetsova M., Khavkin E. Two orthologues of late blight resistance gene $R 1$ in wild Solanum species and derived potato varieties and hybrids. In: PPO-Special Report no. 17. H.T.A.M. Schepers (ed.). Wageningen, 2015: 213-220.

32. Riet man H. Putting the Phytophthora infestans genome sequence at work; multiple novel avirulence and potato resistance gene candidates revealed. PhD thesis. Wageningen University, Wageningen, 2011.

33. Fadina O.A., Beketova M.P., Belyantseva T.V., Kuznetsova M.A., Rogozina E.V., Khavkin E.E. Marker profiles of late blight resistance genes in complex interspecific potato hybrids. In: PPO-Special Report no. 17. H.T.A.M. Schepers (ed.). Wageningen, 2015: 195-201.

34. Segretin M.E., Pais M., Franceschetti M., Chaparro-Garcia A., Bos J.I., Banfield M.J., Kamoun S. Single amino acid mutations in the potato immune receptor R3a expand response to Phytophthora effectors. Mol. Plant-Microbe Interact., 2014, 27(7): 624637 (doi: 10.1094/MPMI-02-14-0040-R). 